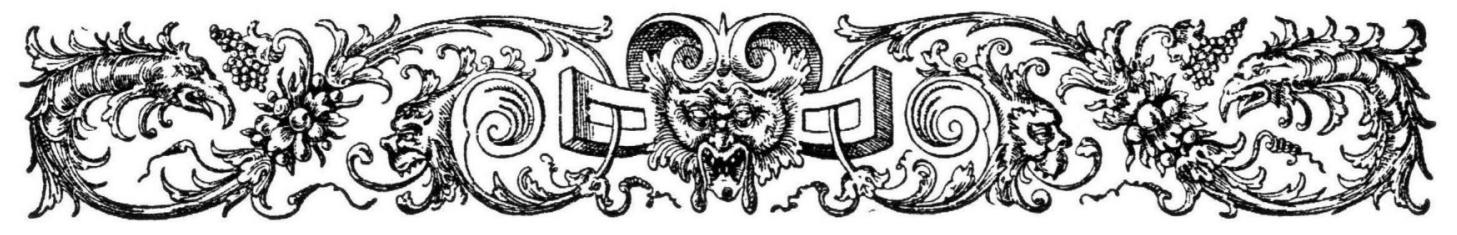

\title{
EENE EPISODE UIT DE GESCHIEDENIS VAN HET POSTWEZEN IN GELDERLAND I733-I735,
}

DOOR

\author{
Mr. DR. J. C. OVERVOORDE.
}

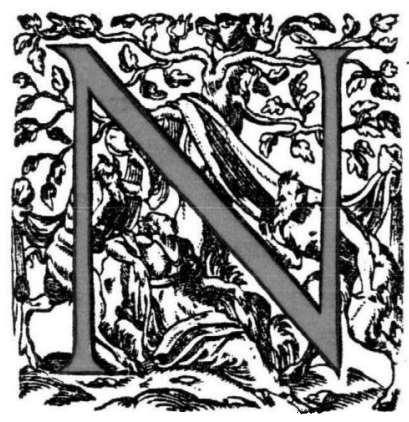

ADAT eerst het postwezen in Gelderland vrijwel geheel aan de steden was overgelaten, werd in I675 NicolaAs FAGEL tot postmeester-generaal voor Gelderland benoemd. 1) Hij werd den 4 April 1695 als zoodanig opgevolgd door FrançoIS VERBolt en deze den 27 April I 700 door J. R. baron VAN KEPPEL, doch na diens overlijden werd dit ambt in 1733 niet meer vervuld en traden de steden weder in het bezit van hare posterijen. ${ }^{2}$ ) Hiervan maakte de Nijmeegsche postmeester M. L. SingENDONCK gebruik, om, buiten de andere Geldersche steden om, eene overeenkomst te sluiten met BORS, den postmeester van de Rijkspost te Maaseik, waarbij hij niet alleen voor de Nijmeegsche brieven contracteerde, doch ook voor het vervoer der brieven van de andere steden, waarmede hij daarna tot overeenstemming trachtte te komen. Hij stelde aan Arnhem, Doesburg en Zutphen voor, dat hij de brieven te Wageningen zoude brengen tegen eene bijdrage in de kosten van het vervoer tusschen Nijmegen en

1) Landdagreces van 18 Maart 1675 .

2) Arnhem trok de posterij aan zich ten bate van de 12 schepenen, die de uitvoering overlieten aan een commies. Zie mijne Geschiedenis van bet Postwezen, blz. 48r. Wageningen benoemde 2 Augustus I734 JOHANNES VAN SCHUYLENBORGH, zoon van den burgemeester JACOBUS Van SCHUILENBORgh, tot post-

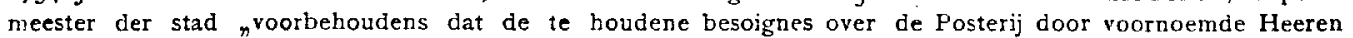
Gecommitteerdens - n.l. L. A. Baron TORCK en D. YAN RUYvEN - sullen waergenomen worden". Resolutie Pslitie en Commissieboek op dezen datum volgens vriendelijke mededeeling van Dr R. JEssE.

Oud Holland, igi6. 


\section{EENE EPISODE UIT DE GESCHIEDENIS}

Wageningen, en om de porten alleen over het traject van Nijmegen af te deelen, zoodat alle bovenporten, - dat zijn de porten voor het vervoer der brieven van de Rijkspost naar Gelderland berekend voor het vervoer tot Nijmegen, - aan hem zouden komen en dus door de andere postmeesters, nadat zij die van de geadresseerden ontvangen hadden, aan hem zouden worden vergoed.

Het Nijmeegsche plan was handig bedacht, en ware het gelukt, dan had Singendonck, die reeds het rit van Wageningen op Utrecht beheerde, zich hiermede vrijwel van het monopolie verzekerd van de Geldersche correspondentie met het buitenland en van de daarmede verbonden, niet onaanzienlijke baten, en zoude hij, wat de buitenlandsche correspondentie betreft, vrijwel in de plaats getreden zijn van den postmeester-generaal van Gelderland. Het plan stuitte echter voorloopig af op den tegenstand van de andere steden, die bezwaar maakten tegen dit eigenmachtig over hunne correspondentie beschikken. Vooral Zutphen en Wageningen waren hierbij de initiatiefnemers tot het verzet, waarbij ook Arnhem later een actief deel nam; Doesburg speelde slechts eene secundaire rol. 1) Tiel en Bommel aanvaardden de door Nijmegen voor hunne correspondentie aangeboden voorwaarden en bleven verder geheel buiten de actie ${ }^{2}$ ). Daarentegen trachtte Grave, dat ook ontstemd was over de slechte door SINGENDONCK aangeboden voorwaarden, met de vier steden in relatie te treden.

$\mathrm{Bij}$ de hierover gevoerde actie traden vooral twee der burgemeesters van Wageningen op den voorgrond, L. A. baron TORCK VAN ROSENDAEL ${ }^{3}$ ) en D. VAN RUYven, en daar Torck een groot deel van het jaar, als lid van de Admiraliteit, te Amsterdam vertoetde, ontstond er over deze postactie eene uitgebreide correspondentie met TORCK, die door een gelukkig toeval bewaard bleef in het familie-archief van baron VAN PALLANDT te Rozendaal. De heer J. W. G. VAN HAARST was zoo welwillend hierop mijne aandacht te vestigen en baron VAN PALlANDT had de vriendelijkheid om mij deze brieven ter bewerking af te staan.

Deze correspondentie levert een nieuwen blik op deze episode in de ontwikkeling van het Geldersche postwezen. Ik laat hiervan een overzicht volgen,

1) Doesburg had eerst slechts een factor van de Brandenburgsche post (sinds $\mathbf{1} 700$ ) en $\mathrm{kreeg}$ in $17 \mathbf{I}_{4}$ een eigen postmeester. VAN RUYven achtte de beteekenis van Doesburg gering en gaf het plan om via Doesburg te rijden terstond op, toen Zutphen daartegen bezwaar maakte.

2) Tiel slont den 18 December 1733 een contract met Singendonck en Bommel den I6 Februari 1734 . Zij ontvingen hunne brieven te Amerongen van den postiljon van Wageningen op Utrecht.

3) L. A. Baron TORCK was een man van veel invloed. Hij was landdrost van de Veluwe, extra-ordinaris raad in het Hof van Gelderland en gecommitteerde in de Admiraliteit van Amsterdam. Hij was met D, vaN RuYven den 3 April 1734 door Wageningen tot gecommitteerde voor de posterij benoemd. Verder trad uit Wageningen WigBoLD SLICHER te 's-Gravenhage op in het belang der postplannen, waar hij vooral werkzaam was om door zijne relatie met den Haagschen postmeester SLICHER nadere gegevens over het postwezen te verzamelen en met den postmeester DiERQuens te onderhandelen. 
als eene aanvulling op mijne "Geschiedenis van het Postwezen in Nederland vór 1795" 1), waarnaar ik hierbij verwijs voor den algemeenen toestand hier te lande. Voor het goede begrip van het hier behandelde moet ik echter een kort overzicht geven van den toestand in Gelderland.

De brieven uit Holland werden door vijf postiljons naar de entreposte van Maria Ysseldijk buiten de Witte Vrouwenpoort bij Utrecht gebracht en daar door haar gesorteerd. Vandaar gingen de postiljons naar Gorinchem en naar Gelderland, waarvan wij thans alleen bij de laatstgenoemden stilstaan.

Er gingen twee ritten via Wageningen, de zoogenaamde Oostersche of Berlijnsche post en het Nijmeegsche rit. Het eerste was een direct rit op Emmerik, waarvan de brieven in een gesloten valies overhandigd werden aan den postiljon Cleynituysen, die het valies buiten de Rijnpoort te Arnhem afgaf aan den postiljon van Pruisen in de herberg, daar Roermonde uithangt. Dit geschiedde buiten de poorten van Arnhem, zoodat noch Utrecht, noch Arnhem eenigen invloed uitoefende op dit rit $^{2}$ ), hetwelk door Dierquens, den postmeester te 's-Gravenhage, werd beheerd en voor rekening van Pruisen werd betaald. Het tweede rit vervoerde de brieven voor de Geldersche steden van Utrecht tot Wageningen, waar de brieven voor Arnhem, Zutphen en Doesburg door den Arnhemschen postiljon werden afgehaald. Het rit werd tot Wageningen door de Rijkspost betaald, die het uitbesteed had aan den postmeester van Nijmegen, die de brieven voor de Rijkspost vandaar naar Nijmegen bracht. Hiermede werden o.a. de brieven medegenomen uit Holland voor Kleef, Grave, Roermond, Maastricht en verder. De brieven voor Wageningen werden aldaar afgegeven en de rest werd door den postiljon van Arnhem naar die stad en verder naar Dieren gebracht, waar Doesburg een voetbode zond en Zutphen een postiljon. Voor het vervoer tot Wageningen betaalden de vier steden eene vergoeding aan SINGENDONCK, waarschijnlijk 500 gulden per jaar, waarvan 45 gulden door Wageningen werd betaald en 240 gulden door Arnhem. ${ }^{3}$ ) Voor den postiljon van Wageningen naar Dieren betaalde Arnhem 400 gulden per jaar, waartegenover het van de andere steden eene kleine tegemoetkoming ontving. Deze bedroeg in 177 I van Zutphen 85 gulden en van Doesburg 30 gulden. Later is dit bedrag verhoogd.

Het Nijmeegsche rit was oorspronkelijk door Pontiann SingendonCK, den eersten postmeester te Nijmegen, den I April 1642 ingericht, in overleg met G. DULCKEN, den postmeester van de Rijkspost te Roermond, een der voorgangers van BORS. Den 27 Mei 1675 sloot N. FAGEL, dan postmeester-generaal van 1) Leiden, Ig02.

2) De brieven voor en van Utrecht werden door een bode van den postmeester te Utrecht aan de entreposte gehaald en gebracht.

3) Brief van Van Ruyvex, ig December 1733. 
Gelderland, een contract met DULCKEN, waarbij hij het vervoer der brieven van de Rijkspost van Nijmegen en terug op zich nam, tweemaal per week voor I 500 gulden per jaar en nog een gulden per postdag voor het vervoer der Geldersche brieven. Dit contract was zeer voordeelig voor FAGEL, daar hij niets betaalde voor het vervoer en hem alle porten gelaten werden van de hem door de Rijkspost gezonden brieven vanaf Keulen en Antwerpen. Alleen de porten van plaatsen boven Keulen en Antwerpen tot die plaatsen had hij aan de Rijkspost te vergoeden. Omgekeerd ontving deze de porten der door Nijmegen gezonden brieven ${ }^{1}$ ).

Den 2 October I 687 sloot FAGEL een tweede contract met de Brandenburgsche post, den concurrent van de Rijkspost, waarbij hij het vervoer op zich nam van de Pruische brieven, die over Kleef naar Nijmegen gezonden werden. Oorspronkelijk werden deze slechts tot Kleef bezorgd en aldaar overgenomen door de postiljons van de Rijkspost, doch sinds de Leidsche postmeester CLIGNET aan Brandenburg het voordeel van een eigen postverbinding met Holland had aangetoond, trachtte de keurvorst buiten de Rijkspost om in contact te komen met Holland. Na verschillende mislukte pogingen ${ }^{2}$ ) sloot hij het contract met FAGEL, waarbij deze het vervoer op zich nam voor 4000 gulden per jaar. ${ }^{3}$ ). Dit contract werd door FAGEL als particulier gesloten en ging niet over op zijnen opvolger als postmeestergeneraal van Gelderland. Het vervoer werd in 1697 overgedragen aan de familie SCHUYlenbURG, naar wie het later gewoonlijk het Schuylenburgsche rit werd genoend. Het ressorteerde sinds 1698 onder het toezicht van den postmeester te Emmerik. Deze verzending verloor later aan beteekenis tegenover de route van Emmerik op Arnhem.

In 1700 werd door VAN KEPPEL een contract met de Rijkspost gesloten, waarbij de toezending der brieven over Boekholt werd geregeld. De brieven werden franco aan de Landweer geleverd en daar door VAN KEPPEL afgehaald. In 1717 volgde een nieuw contract met BORS, waarbij hiervan weder werd afgeweken en de toezending der brieven van Maaseik over Roermond naar Nijmegen werd geregeld. Dit was geschied op verlangen van BoRs, die op deze wijze via Wageningen en Utrecht een tweeden weg openhield voor zijne correspondentie met Holland, indien door oorlog of ijsgang de route door de Meierij op Gorinchem verbroken werd.

De postmeester te Nijmegen was hierdoor de aangewezen man om met de Rijkspost te contracteeren, toen na den dood van VAN KEPPEL in 1733 geen postmeester-generaal meer werd benoemd, en waarschijnlijk zouden de andere

1) Zie mijne Geschiedenis van het Postwezen blz. 486 .

2) Zie aldaar bl. $x 68$.

3) Dit bedrag werd in 1698 verlaagd tot 3000 gulden en in I 719 tot 2500 gulden. 
steden, evenals Tiel en Bommel hierin hebben berust, wanneer niet door SINGENDONCK aanspraak was gemaakt op vergoeding van alle bovenporten boven Nijmegen.

Over het algemeen gold als regel, dat die postmeester de porten ontving, die ook het vervoer betaalde, en SINGENDONCK zoude dus volkomen tot de bovenporten gerechtigd geweest zijn, indien door hem ook een deel was betaald van het vervoer der brieven van het kantoor der Rijkspost te Maaseik tot Nijmegen. Men vermoedde echter, dat dit niet geschiedde, evenmin als tijdens FAGEL, en dat hij zich dus ten koste der andere Geldersche steden een overmatig voordeel trachtte te verzekeren. Wel grondde hij zich bij zijn eisch op de zware lasten, hem door het contract met de Rijkspost opgelegd, doch toen men hem vroeg om dan van dat contract inzage te geven en aldus te laten zien welke lasten hem opgelegd waren, weigerde hij dit, waardoor de steden niet ten onrechte tot de overtuiging kwamen, dat hij meer vroeg dan noodig was. Ook hinderde het haar, dat aldus door den Nijmeegschen postmeester buiten haar om over hare correspondentie met de Rijkspost werd beschikt.

De oppositie werd begonnen door Zutphen en Wageningen. Zutphen meende wel buiten Nijmegen om met de Rijkspost langs de oude route van vóór I $7 \mathbf{I} 7$ in contact te kunnen komen en Wageningen hoopte een voordeel te kunnen trekken uit de wisseling der brievenmalen aldaar. Uit een brief van VAN RUYveN van I6 Januari I733 blijkt, dat Wageningen reeds toen in onderhandeling was met Zutphen; de overige steden waren wel gebelgd over de hooge porten door SiNGENDONCK gevraagd, doch waren nog niet tot ernstige oppositie geneigd en ook Zutphen had eerst getracht een contract met Nijmegen te sluiten, dat echter afgesprongen was op de vergoeding der bovenporten. Den 24 April schrijft VAN RUYven: "het is waarschijnlijk, dat er tusschen hem (SiNGENDONCK) en de steden Zutphen, Arnhem en Doesburgh wel in korten meerder misnoegen sal komen, waarvan wij, so sulx tot een geheele rupture quam, ons gebruyk souden kunnen maken, terwijl wij, met commoditeyt die klught aanschouwende, het vuurtje soetjes kunnen aanstooken."

Het plan van Torck en VAN RUyven was oorspronkelijk om te trachten de directie te verkrijgen van het rit van Wageningen op Utrecht, daarna een contract te sluiten met de Rijkspost en met Berlijn en aldus eenig voordeel te vermeesteren voor Wageningen. TORCK wilde, volgens schrijven van 20 December I733, de baten tusschen de vier steden verdeelen, doch VAN RUYVEN antwoordde hierop den 30 December: ,belangende de verdeelinge van d'huyd van den Beer, soude $\mathrm{ik}$, salvo vestro meliori judicio, van gevoelen wesen, dat ieder der drie steeden $Z$ (utphen), $A($ rnhem) en $W$ (ageningen) behooren te hebben de directie van haare postiljons en ritten, en dat $A($ rnhem) en $D$ (oesburg) behooren vergenoeght 
te wesen, als die door onse industrie vrij en buyten haare tegenwoordige belastinge haare ritten konden hebben. Voort dat, als er overschot over de massa konden vallen, als $t^{\prime}$ hoopen en wenschen is, dat dien overschot egaal tusschen $\mathrm{Z}$ (utphen) en W(ageningen) wierde gepartageert voor belooninge van de vangst van den Beer." Ook later erkent VAN RUYveN de bedoeling van eigen voordeel voor Wageningen in een schrijven aan $\mathrm{TORCK}$ van 5 Januari 1735, waarin hij schrijft: „Nu wij aan het kluwen geraaken, vinde ik niet die avantage voor onse stad, die ik mij altoos verbeeld hadde, namentlijk om afsonderlijk onder d' hand meester van de Berlijnsche postrit te werden." Hij had toen reeds ingezien, dat er alleen door samenwerking van de steden iets te bereiken zoude zijn. Men begon daarom met de steden zooveel mogelijk tegen SINGENDONCK op te zetten en voorloopig beperkten deze zich tot het in dergelijke gevallen veel toegepaste middel om betere voorwaarden te verkrijgen, door de afrekening der bovenporten met Nijmegen te weigeren. BoRs schrijft in November 1734, dat de steden reeds sinds 13 maanden in gebreke waren, waarschijniijk is men dus in Augustus 1733 hiermede begonnen. Toen Zutphen beweerde een weg te weten om buiten Nijmegen om de correspondentie te voeren, noodigde VAN Ruyven de Zutphensche heeren tot eene conferentie met hem uit, die den 24 Januari 1734 te Arnhem plaats vond. De beide HASEBroEk's, de burgemeester en de postmeester uit Zutphen, ontwikkelden hier een plan, dat wij straks nader zullen bespreken. 1)

Spoedig bleek het gewenscht om eene conferentie te houden met de vertegenwoordigers van de vier in oppositie zijnde steden Arnhem, Zutphen, Wageningen en Doesburg, welke op verzoek van Zutphen, hierbij vertegenwoordigd door van GOLSTEYN en HASEBROEK, werd bijeengeroepen en den 5 April 1734 te Arnhem werd gehouden. ${ }^{2}$ )

1) Te Zutphen had Mr. HARMEN HASEBROECK als commies van den postmester generaal VAN KEPPEL het postkantoor beheerd. Na diens dood werd hij bij resolutie van den raad van 30 Juni $\mathbf{1} 733$ gemachtigd om de posterij bij provisie waar te nemen en 9 Januari 1734 werd hij definiticf tot commies aangesteld. Hij overleed in I 735 en I Maart 1735 werd zijne weduwe met de commiesplaats begiftigd. Hij was een neef van den Zutphenschen burgemeester Mr. Herman Hasebroeck. (Mededeeling van den Heer J. GIMBERG te Zutphen).

2) Zie over de conferentie ook het Commissie- en Politieboek van Arnhem, 23 Mei I735 (dl. 1729-35 blz. 456). ${ }_{n}$ Nog door den mede schepen van HARN en andere Haer WelEd. en de Agtb. gecommitt. tot de posterije gerapporteert sijnde, dat verscheide conferentien tussen de steden en de burgemr. M. L. SingendoncK, heer van Dieden, gehouden waren over het reguleren van 't gene van het overbrengen der foraine brieven aan gen. burgemr. SinGENDONCK door deselve steden soude goetgedaen worden, dat in de eerste conferentie door deselve burgemr. geëist geworden 't halve port van 't gene voor de foraine brieven betaalt wierd tot Zutphen, Doesburg en Arnhem, dog dat dit bij de steden, nadat daerover met malkandere hadde gebesoigneert aen gen. heer van Dieden was bekent gemaekt, dat men tot dien eis als seer exorbitant zijnde, geensints konde verstaen, nog die oyt soude amplecteren, maer liver het uyterste hazarderen, welle feimeteit bij denselve bespeurt sijnde, so had opregtelijk en met kragtige uitdrukkinge betuygt ende verclaert dat de foraine brieven van 't postcomtoir van BORS ter sijnen kosten en door zijn eige postilion by sijn Ed. betaelt wordende moest laten afhalen en na Nijmegen transportere en dit diensvolgens redelijk was, dat de stecien hem daerin te gemoet 
Het bleek hier, dat Arnhem en Doesburg wel tot toegeven geneigd waren, doch HASEBROEK en VAN RUYVEN wisten door te drijven, dat men besloot om de afrekening te blijven weigeren, 1) zoolang door SINGENDONCK niet voldaan werd aan het verzoek van de steden, en om een anderen weg voor de correspondentie te zoeken, voor het geval SINGENDONCK zich hiertegen mocht blijven verzetten. Men meende, dat SINGENDONCK niets aan de Rijkspost betaalde voor het vervoer tot Nijmegen, en dus ook geen recht had op de bovenporten tot Nijmegen, en drong daarom zoo op de overlegging van het contract aan, teneinde betere voorwaarden te kunnen bedingen. Fene nadere conferentie volgde den 16 April I734 te Nijmegen, waarbij bleek, dat reeds besprekingen gehouden waren met Grave, dat ook wegens de hooge porten met SINGENDONCK op gespannen voet stond.

De steden bleven voorloopig de betaling der bovenporten weigeren, doch verklaarden zich tot nader overleg met Nijmegen bereid, indien dit het contract wilde overleggen. Het was toch wél gemakkelijk om de brieven langs een anderen weg, b.v. over Utrecht en Gorinchem, te verzenden, doch moeilijker zoude het vallen om de Rijkspost te bewegen om dien weg ook voor de brieven naar Gelderland te gebruiken, zoodat men daarbij toch aan de genade van Nijmegen zoude overgeleverd blijven. BORS deed hierop de brieven voor de steden ophouden, waarop de Gecommitteerden van Arnhem, Zutphen en Doesburg zich den 16 November 1734 ernstig bij hem beklaagden. ${ }^{2}$ ) $Z_{i j}$ drongen aan op toezending der drie opgehouden zendingen en verklaarden zich bereid om eene vergoeding te betalen, wanneer het contract werd overgelegd. Dit werd door SinGENDONCK geweigerd. Hij bleef vergoeding van alle bovenporten boven Nijmegen eischen, doch verklaarde zich bereid om een nader contract te sluiten. Hij baseerde zijne hooge eischen op de zware lasten, die hem door het contract met de Rijkspost waren opgelegd. Zelfs verweet hij aan de oppositiesteden een "leonine societeyt" te willen sluiten, 3) daar zij wél van de voordeelen van het contract wilden genieten, doch niet mede in de lasten dragen. Werkelijk waren de voorwaarden

quamen en pro rato daerinne mede lastede, so als deden met de postillon van Nijmegen op Wageningen en Utregt, sig uytbidende om daerover met welgen. steden op sekeren vast te stellene dag, door sijn Ed. nader bekent te maken, binne Arnhem in conferentie te treden, om in derminne 't montant van dien te regulere, ' $t$ geen bij de respective steden was aengenomen. Welk gerapporteerde Haer WelEd. en Agtb. sig hebben laten welgevallen, bedankende gecommitt, voor haer genomene moeyten en gedane rapport". (Mededeeling van den Heer J. W. G. VAN HAARST) zie ook Resolutie, Politie en Commissieboek van Wageningen 3 April I734.

1) Doesburg ging zelfs zoover om hangende de geschillen zelfs zijn aandeel in het rit van Wageningen op Utrecht niet te betalen, waarover SINGENDONCK zich den I8 December I734 terecht bij G. OpteN NoorTH beklaagde. Deze was secretaris van Arnhem en van 1720-1740 substituut momber van het vorstendom GeLRE en het graafschap Zutphen.

2) Wageningen had oorspronkelijk slechts een postfactor en geen postmeester. Het stond niet in relatic met de Rijkspost en blcef daarom voorloopig officieel buiten de geschillen.

3) Brief aan G. Opten NOORTH, 23 November 1734. De uitdrukking schijnt in een gesprek gebezigd te zijn; SINGENDONCK nam die later terug. 
voor hem bezwarender, dan volgens het indertijd door FAGEL gesloten contract, doch toch waren de voordeelen nog groot genoeg, dat wij volkomen begrijpen, dat hij hiervan geen inzage wilde verstrekken.

$\mathrm{D} \approx$ Gecommitteerden wendden zich met die van Wageningen ook direct tot Bors te Maaseik, waarbij zij nogmaals op overlegging van het contract aandrongen en ook aanboden om zelfstandig met de Rijkspost te contracteeren en hunne brieven in gesloten paketten te ontvangen. $\mathrm{Zij}$ boden hierbij aan om eene bijdrage in het rit op Utrecht te betalen. BoRS antwoordde hierop den 23 November, in een uitvoerig schrijven, waarin hij de bezwaren der steden trachtte te weerleggen: de overlegging van contracten aan derden was geen gewoonte; de Rijkspost contracteerde o.a. met de Noordsche rijken over de toezending der Italiaansche en Fransche brieven, doch daarbij was nooit sprake geweest van het overleggen van de contracten door de Rijkspost met anderen gesloten voor het vervoer dier correspondentie. De steden konden dus evenmin aanspraak maken op overlegging van het contract met Singendonck. Zij hadden evenmin recht om zich gebelgd te toonen over dit contract; hij had over de Geldersche brieven met den Nijmeegschen postmeester gecontracteerd, omdat van die zijde hem het eerste hierom was gevraagd, en de bezwaren tegen de wijze van embaleeren misten allen grond, daar deze wijze cok vóór het contract met VAN KEPPEL was gevolgd en toen nooit eenig bezwaar had opgeleverd. Ten slotte wees hij er op, dat hij een blijk van welwillendheid tegenover de oppositiesteden had gegeven door eerst I 5 maanden, nadat deze begonnen waren om de bovenporten te weigeren, de brieven op te houden; hij beloofde die nu weder als vroeger toe te zenden, in het vertrouwen, dat de steden het wel spoedig met SINGENDONCK zouden eens worden.

Eene nadere toelichting gaf BORS in een schrijven aan SINGENDONCK van 26 November 1734, dat deze aan de steden mededeelde, en dat blijkbaar ook hierop was berekend. Hierin wijst BORS er op, dat de steden wel eene bijdrage betaalden voor het vervoer der brieven van Wageningen naar Utrecht, doch dat zij geen aandeel hadden in de directie over dit rit en dus ook op geen medezeggingsschap daarbij konden aanspraak maken. Veel belang had dit rit trouwens niet voor hem, daar er slechts weinig brieven naar Holland over Gelderland gingen; hij hield het rit slechts aan om geen nieuwe maatregelen te moeten nemen, als de hoofdroute door de Meierij op Gorinchem door oorlog mocht gestremd worden, wat slechts éénmaal noodig bleek, en wel in het begin van den laatsten oorlog tegen Frankrijk. Mochten de steden blijven weigeren, dan was hij bereid om de brieven niet meer langs deze lijn te vervoeren, doch de steden moesten wel weten, dat dan de porten voor de Geldersche brieven door 
hem veel hooger moesten berekend worden. 1) Ten slotte dreigt hij om de brieven opnieuw te doen ophouden, indien de steden blijven weigeren om de porten te betalen, en hij verklaart, dat hij niet ongerust is over de repressaillemaatregelen, die de steden voor dat geval in het vooruitzicht stellen.

Het door dit schrijven beoogde doel om de steden tot toegeven te bewegen werd echter niet bereikt. De steden bleven de afrekening weigeren en den 6 December schrijft Singendonck aan OPTEN Noorth op "het gedienstigst te versoecken en 't' insisteren, ten einde hoe eer soo beter een afcomst van de saken in questie mag worden gemaakt, opdat de langere trainissementen de keyserlijke postcomtoire niet weder verdrietig mogen comen te vallen en weder van nieuwe doen resolveren tot mesures, die niet anders als nadelige confusen konnen na sig slepen, dewelke immers vrij beter was eenmael te provenieren en volkomen uyt den wegh te ruymen". Toen ook dit nog niet hielp, drong SInGEndonck den 23 December opnieuw bij OPTEN NOORTH op betaling aan, onder bericht, dat BORS niet geneigd was om nog langer dan een paar weken uitstel te verleenen.

De repressaillemaatregelen van de steden, waarop BoRs doelt, konden behalve in het zoeken van een anderen weg voor de correspondentie, bestaan in het bemoeilijken van het rit door Gelderland. Daartoe toch was nooit officieel verlof gevraagd en de steden konden dus trachten om dezen "gesmokkelden postiljon", gelijk VAN RUYVEN hem in een brief aan TORCK noemt, in het rijden over Geldersch territoir te bemoeilijken. VAN RUYven meende zelfs, dat het dreigen hiermede voldoende zoude zijn om DIERQuens, den postmeester te 's-Gravenhage, nader tot de oppositiesteden te brengen.

Deze zaten ondertusschen niet stil; zij trachtten in de eerste plaats achter den rug van Nijmegen om inzage te krijgen van het contract, en wendden zich hiertoe tot WITTENHORST, een postmeester van de Rijkspost, van wien men wist, dat hij met Bors op gespannen voet verkeerde. ${ }^{2}$ ) Ook liet men er naar informeeren door een magistraatspersoon te Maastricht, waarover BORS zich ontstemd betoonde ${ }^{3}$ ). Al deze pogingen bleven echter zonder gevolg. Men trachtte nu buiten Nijmegen om direct met de Rijkspost in contact te komen, doch Bors

1) Het vervoer naar Gelderland was ook van weinig beteekenis. BoRs schrijft, dat hij voor Zutphen en Doesburg sinds jaren geen vreemde bricven over Wageningen had gezonden.

2) Brief van VAN RUYren, 6 Maart I734,

3) Brief van Singendonck van 13 Januari 1735, waarbij hij het dreigement van Bors herhaalt. Naar de Heer Van Schevichaven zoo welwillend was mij te berichten, is er in het Gemeente-archief te Nijmegen noch het contract, noch eenige aanteekening over den strijd met de oppositiesteden te vinden. Men mag dus aannemen, dat de geheele zaak door SinGENDONCK als postmeester buiten de stadsregeering om is behandeld. Het contract, van 2 Juli ${ }^{7333}$, werd door mij teruggevonden in het Geheime Post-archief te Berijjn en in mijn Geschiedenis van het Postwezen $(b 1,488)$ in het kort vermeld. De route via Nijmegen had voor de Rijkspost aan belang verloren sinds de inrichting van het rit door de Meierij en Drunen, zoodat ook de Rijkspost niet Oud-Holland, rgi6. 
weigerde dit terstond, op grond van zijn contract met Nijmegen, waarbij hij beloofd had om alle Geldersche brieven via Nijmegen te zenden; men moest nu dus trachten om buiten hem om met TAXIS zelt te onderhandelen.

Hiertoe werden langs allerlei wegen pogingen gedaan. Door bemiddeling van den Zutphenschen burgemeester werd de graaf VAN FLODORP bereid gevonden om met TAXIS, die zich toen tijdelijk te Brussel bevond, te gaan spreken. Hij verklaarde echter hiervan weinig te verwachten, daar $T_{A X I S}$ toch niets zoude doen zonder het advies van zijne postmeesters BORS, WEVELINKHOVEN en WITTENHORST. Alleen deze laatste zoude wellicht voor het pian te vinden zijn uit naijver tegen BoRs. Vooral zoude het goed zijn om tevoren steun te zoeken bij de Amsterdamsche postmeesters, daar Amsterdam "als de brantklok (is) in 't postwezen, en waeruyt en nae toe, als een sak, álle brieven moeten komen"1).

Gelijktijdig werd J. VAN HAMEL BRUYNINCX te Weenen door TORCK bewerkt ${ }^{2}$ ) en wendde deze zich op diens verzoek tot den Hollandschen resident Spina te Frankfort, aan wien ook reeds door VAN RUyven, die hem wel eens ontmoet had, geschreven was. ${ }^{3}$ ) Ook VAN GINKEL, de Hollandsche gezant bij Pruisen, wendde zich tot TAXIS, doch juist door dit aandringen van verschillende zijden werd bij TAXIs achterdocht opgewekt, zoodat deze zich om inlichtingen wendde tot VoN BIELSTEYN, zijnen agent te Weenen, en tot BORS te Maaseik, van wien in dit geval zeker niet een gunstig advies te wachten was. Later werd ook nog de hulp van graaf SINZENDORF ingeroepen en trachtte ook graaf van LIJNDEN bij TAXIS in het belang der vier steden te werken. ${ }^{4}$ ) Door hem werd in overweging gegeven om de brieven van Maaseik mede te geven aan den postiljon naar Nijmegen, hem deze te Mook te laten afgeven en verder over Grave naar Wageningen te doen zenden.

Het oorspronkelijke plan, door HASEBROEK geopperd, was om de Rijkspost te bewegen om de brieven weder, als vóór I7I7, over Boekholt te zenden. Hierdoor zoude men zoowel in tijd als in geld eene besparing verkrijgen; terwijl tevens de Geldersche brieven dan direct ontvangen werden en niet meer een

meer zóó toeschietelijk was, als in den tijd van FAGEL. Nijmegen behield de porten van Maaseik af, doch moest de bovenporten vergoeden, dus ook die tusschen Keulen of Antwerpen en Maaseik, die vroeger aan FAGEL. waren gelaten. De porten der brieven naar Maaseik bleven voor de Rijkspost, en voor de hoogerop gelegen plaatsen moesten de frankeergelden bijgezonden worden. Nijmegen had niets te betalen in de kosten van het rit naar Maaseik, dat geheel ten laste van de Rijkspost bleef, en zelfs werd aan SINGENDoNCK als gunst toegestaan om kosteloos zijne brieven of Holland in te sluiten in het Hollandsche pakket van de Rijkspost, dat via Wageningen naar Uirecht werd gezonden.

1) Brief van burgemeester HASEBROEk te Zutphen, I Jauuari r734.

2) Deze stond in relatie met TORCK; VAN RUYVEN noemt hem zelfs diens broeder. Volgens de mij door Jhr. Mr. W. A. BeELAERTs vas BLokLANd verstrekte inlichting bestond er tusscben hen echter geen familieband.

3) Brief van J. VAN Hamed BRUynincx, I3 Januari I734.

4) Brieven van 5 Maart, 23 en 24 April 1734 . 
omweg behoefden te maken. Ook zoude aan deze route het voordeel verbonden zijn, dat men niet verschillende groote rivieren te passeeren had. ') Volgens de door HASEBROEK gemaakte berekening zouden volgens de voorgestelde route de brieven in $24^{1 / 2}$ uur van de grens naar Amsterdam gebracht kunnen worden volgens onderstaande indeeling, waarbij er rekening mede gehouden was, dat de weg boven Dieren dikwijls drassig was en dus meer tijd vorderde.

Volgens HASEBROEK zouden de postiljons Dinsdag en Vrijdag om I uur uit Amsterdam vertrekken, in $21 / 4$ uur, met den tijd voor het verwisselen, naar Halfwegen en in $2 y_{4}$ uur van daar naar Utrecht, alwaar een uur halt gehouden werd voor het verwisselen der brieven in het entrepostkantoor buiten de Witte Vrouwenpoort. De postiljon vertrok vandaar om 7 uur n.m., reed in $21 / 4$ uur naar Doorn en in $23 / 4$ uur van daar naar Wageningen, waar weder een uur oponthoud was voor het verwisselen der brieven. Het vertrek werd gesteld op r2.30 en de aankomst te Arnhem op 2 uur 45 v.m., waarna weder tot 3 uur tijd gelaten werd voor het verwisselen. Daarna werd doorgereden naar Dieren, aankomst 5.30 v.m., en naar Zutphen, alwaar weder van 8 tot 9 uur v.m. tijd vrijgehouden werd voor de behandeling der brieven. Ten slotte reed de postiljon van daar in 4 uur naar de Landweer en in 2 uur naar Aalten, en van daar in I uur naar de grens, waar hij om 3 uur n.m. kon aankomen. De onkosten werden begroot op 4750 gulden, en wel:

postiljon met paard van Amsterdam naar Halfwegen . . . . $f$ 600.van daar naar Utrecht . . . . . . . . . . . . ,600.-

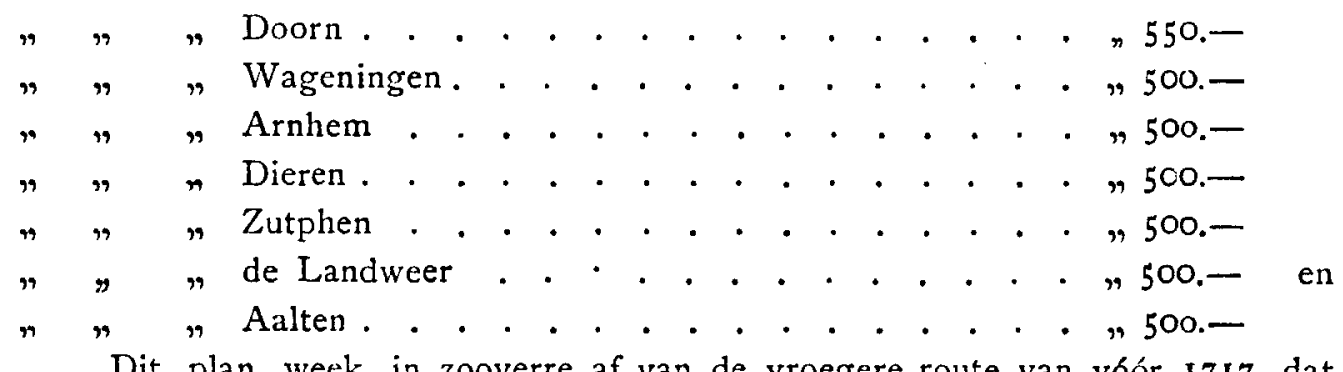

Dit plan week in zooverre af van de vroegere route van vóór 1717, dat

1) De brieven gingen eerst op Amsterdam en werden vandaar met het Geldersche rit op de Geldersche steden gexpedieerd. Bij de nieuwe route zoude men alleen de Ysel te passeeren hebben over een vaste brug, terwijl de route door de Meierij over Drunen driemaal een rivier moest oversteken. Zie den brief van ToRck van 20 December 1733. VAN KEPPEL ontving volgens VAN RUYVEN intertijd voor dit rit I0.000 guiden per jaar, terwijl hij zelf aan den postiljon CASPER VAN HOLTEN slechts I roo gulden betaalde, - (waarschijnlijk was deze wel verwant aan Johan van Houren, die den ro December r710 te Arnhem zijne schoonmoeder NALCKEN JANSEN, weduwe VAN SWEER OYMANS als besteller der Utrechische en Amsterdamsche brieven opvolgde; NALCKEN zelf was daarmede 8 Februari 1680 belast, zie mijne Geschiedenis, bl. 484).

Het plan van HASEBroek voor de nieuwe route is nader uitgewerkt in diens brief van I Januari 1734 . De brieven gingen vóór I 717 van de grens over Boekholt, Heiden, Dorster en Batterop naar Pempelfort, dat $1 / 2$ uur van Keulen lag. 
thans Doesburg niet werd gepasseerd. Dit geschiedde op verzoek van Zutphen, dat tegen de route over Doesburg had bezwaar gemaakt, „zoodat Doesburg niet in consideratie kan komen." De brieven voor Doesburg zouden nu te Dieren worden afgehaald. 1)

Eerst meende men, dat het rit naar Utrecht door de Amsterdamsche postmeesters werd beheerd en hoopte van hen gedaan te krijgen, dat de oude route werd hersteld en dat dan het vervoer aan de steden zoude uitbesteed worden. Spoedig bleek echter, dat Bors de man was, die de postiljons betaalde en die de directie had over het Nymeegsche rit. ${ }^{2}$ ) Eene poging om hem te bewegen om althans het rit van Wageningen op Utrecht aan de steden over te laten, waardoor deze in directe verbinding met Holland zouden gekomen zijn, stuitte terstond af op diens weigering. Trouwens van Bors, dien een der correspondenten qualificeert als "zijnde bekent voor een doortrapt man", was niet aan te nemen, dat hij op dit verzoek zoude ingaan, al maakten de steden het hem ook aanlokkelijk door hiervoor slechts 900 gulden per jaar te vragen, dus veel minder dan BORS aan SingendonCK betaalde. ${ }^{3}$ )

Het geheele plan om tot de oude route terug te keeren stuitte ten slotte af op de weigering van TAXIs, die den I6 April 1734 antwoordde, dat hij niet met de vier steden in relatie kon treden, daar hij zich bij het contract met van SINGENDONCK verbonden had om alle Geldersche brieven via Nijmegen te zenden.

Er bleef nu niets anders over dan toegeven of buiten de Rijkspost om een anderen weg voor de correspondentie te zoeken. Dit laatste was reeds lang door Wageningen en Zutphen overwogen, doch het schijnt, dat de andere steden hierbij maar gedeeltelijk in het vertrouwen genomen waren.

Twee wegen stonden hiertoe open: eene directe overeenkomst met de Pruisische post of eene aansluiting over Grave. Dit laatste werd wel overwogen, doch bleek weldra onuitvoerbaar, daar Grave geen eigen verbindingen had en alleen via Nijmegen brieven van de Rijkspost ontving en per voetbode brieven uit 's-Hertogenbosch deed halen. ${ }^{4}$ )

Reeds 30 October bood de ambtman van Grave en van het land van Kuik aan om de brieven uit Holland en Gelderland voor Grave en omliggende plaatsen, zooals Boxmeer en Ravestein, tweemaal per week door een postiljon te Wageningen te doen afhalen en om de brieven van 's-Hertogenbosch, Breda en het verdere gedeelte van Brabant, die door den bode van 's-Hertogenbosch op Grave gebracht

1) Brief van VAN RUYven, 30 December 1733 .

2) Brief van ToRCK, zo December 1733 .

3) Brief van 6 November 1733 .

4) Grave had reeds in 1648 een bode voor de brieven. 
werden en nu op Nijmegen gingen, in het vervolg op Wageningen te dirigeeren. ${ }^{1}$ ) Grave zoude dan zelf den postiljon op Wageningen betalen en was bereid om daarenboven pro rato in de kosten van het rit van Wageningen op Utrecht bij te dragen. De ambtman verzocht om op dezen grondslag een contract voor drie jaren te sluiten. Blijkbaar waren aan dezen brief reeds mondelinge besprekingen vooraf gegaan. Eerst stelden de oppositie-steden zich nog al wat voor van de medewerking van Grave, daar men hoopte langs Grave, met de Rijkspost in contact te kunnen komen zonder Nijmegen aan te doen, hetgeen mogelijk zoude zijn, indien de brieven voor de Geldersche steden in het pak voor Grave gedaan werden. Dit werd echter door Bors belet door te weigeren om de brieven voor Grave in een gesioten pakket te verzenden. Hij wilde die alleen los verzenden, waardoor het bijvoegen van de Geldersche brieven onmogelijk werd. 2) Het belang van een nader contract met Grave werd daardoor geringer en men achtte het te Wageningen daarom beter om zich niet te binden. Ten einde nu niet terstond met Grave te breken, rekte men de zaak door te vragen wat met de bijdrage „pro rato" werd bedoeld, Grave schijnt spoedig ingezien te hebben, dat men de zaak op de lange baan wilde schuiven en werd ongeduldig ${ }^{3}$ ), doch te Wageningen werd men ook huiverig om een contract te sluiten, al had men reeds met Cleynhuysen, den postiljon op Utrecht, een afspraak gemaakt, waarbij deze zich verbond om met het Wageningsche pakje ook de brieven van Grave te vervoeren. Deze wijze van verzending was echter zeer onzeker, daar dit vervoer slechts ter sluiks geschiedde en elk oogenblik op bevel van DIERQueNs, den postmeester te 's-Gravenhage, kon gestopt worden. Aan de medewerking van Grave, dat weldra inzag, dat op deze wijze geen voordeel te behalen viel, kwam nu spoedig een einde. Het gaf de oppositie op en sloot reeds vóór 14 Februari 735 een contract met SingENDonck.

Ondertusschen was reeds langs verschillende wegen getracht met de Pruisische post in relatie te komen. Daarvoor was een eerste vereischte om op de hoogte te komen van de wegen, waarlangs de correspondentie geschiedde, hetwelk nog niet zoo gemakkelijk was bij de geheimzinnigheid, waarin alles, wat het postwezen betrof, gehuld was. Dit toch was in die dagen niet een tak van dienst in het algemeen belang, maar een bron van inkomsten voor de postmeesters die op verschillende wijze elkander concurrentie aandeden en dus hun dienstgeheimen zooveel mogelijk voor derden verborgen hielden.

Eerst trachtte men inzage te krijgen van de papieren van den overleden postmeester-generaal VAN KEPPEL, en men vond den Waldgraaf VAN WELDEREN

1) Afgedrukt in Bijdr. en Mededeel, van Gelre, 1902, bl, 208.

2) Brief van VAN LiJnDEN, 20 Februari 1734.

3) Brieven van 20 en 23 December 1733 . 
bereid om bij de weduwe van baron VAN KEPPEL navrage te doen naar deze bescheiden, doch het bleek daarbij, dat de koffer met papieren geen bescheiden over het postwezen bevatte, daar men alle stukken over de posterij zoo spoedig mogelijk had verbrand 1 ). Men begon nu met den postiljon CleyNHUYSEN, die de brieven voor Pruisen tusschen Utrecht en Arnhem vervoerde uit te hooren, doch deze hield zich van den domme. Men had hem niet alleen te Wageningen, maar ook te Arnhem om inlichtingen gevraagd en hij begreep blijkbaar, dat $z$ wijgen voorloopig het beste was ${ }^{2}$ ). Zijn zoon viel echter spoediger door de mand en zoo kwam men op de hoogte van het vervoer en de inrichting van de entreposte bij Utrecht. $\mathrm{Na}$ veel navragen in den Haag bij DEDEL en SLICHER bleek, dat het rit door DIERQuENs te's-Gravenhage werd betaald namens de Pruisische post. Het bleek hierbij ook, dat de factrice bij Utrecht, juffrouw YSSELDIJK, goed aangeschreven stond, doch dat het oordeel over den postiljon minder gunstig luidde. De postmeester Löckel te Emmerik schrijft van hem den I5 December 1734, dat hij, ,is vor erst een loderlichen kerel, die sich altemets vol supt", en daardoor nooit op tijd aankwam. Misschien was dit ook wel gedeeltelijk te wijten aan het door hem op groote schaal toegepaste misbruik van smokkelbrieven mede te nemen, die hij voor eigen rekening bezorgde ${ }^{3}$ ). Het was blijkbaar een man, die het niet zoo nauw nam, wanneer er voor hem zelf een voordeeltje viel te behalen, een man, waarmede te spreken viel, en VAN RUYvEN makte hiervan gebruik om met hem een afspraak te maken om, buiten zijnen chef om, een pakje met brieven voor Wageningen mede te nemen. Wij komen hierop nader terug.

Langs verschillende wegen verschaften de Wageningsche burgemeesters zich langzamerhand de kennis van het postwezen, die voor de verdere ontwikkeling van hunne plannen noodzakelijk was. Wij zullen hierbij thans niet uitvoerig stilstaan; allerlei familie- en vriendschapsverbindingen werden te hulp geroepen en men slaagde dan ook vrij wel; alleen het contract tusschen Nijmegen en de Rijkspost bleef voor de heeren een gesloten boek.

$\mathrm{Zij}$ begrepen, dat het nu niet meer ging om een plaatselijk voordeel voor een der steden, maar dat alleen het gezamenlijk optreden der vier steder nog eenige kans op slagen bood ${ }^{4}$ ). Daartoe was het eene eerste vereischte, dat men op samenwerking kon rekenen en daarom werd eene nieuwe conferentie der steden

1) Brief van 20 Januari 1734 .

2) Hij weigerde te zeggen wie hem betaalde. Brief van VAN RuyvrN, $1_{3}$ Febr. 1734.

3) Brief van 14 Mei I734.

4) Zie den hierbij als bijlage opgenomen brief van VAN RuYvrav van 5 Januari 1735 . 
gewenscht geacht, vooral, daar men meende, dat Arnhem wel tot toegeven bereid was en althans wel een voorloopig contract voor drie jaar met SINGENDONCK wilde sluiten. Er kon aldus oneenigheid komen tusschen de steden en allicht zoude Arnhem, door afzonderlijk een contract met SINGENDONCK te sluiten, zich eenige voordeelen bedingen en aldus feitelijk met het voordeel gaan strijken, terwijl de overblijvende drie steden niet voldoende beteekenis hadden om alleen den strijd tot een goed einde te brengen, 1 ). Hij raadt daarom ook aan om niet te veel bijzonderheden over de loopende onderhandelingen mede te deelen.

De conferentie werd te Dieren gehouden. TORCK was verhinderd en VAN RUYveN schrijft hem 16 Februari 1735, dat Arnhem wel tot toegeven geneigd was, en ook van GolTsteyN uit Zutphen, doch dat HASEBroeK en Verstege zich ferm hielden, zoodat een voor het verzet gunstig besluit kon genomen worden

De bemoeiïngen voor het eigen rit namen onderwijl een minder gunstige wending. Men had oorspronkelijk gehoopt Pruisen tot een open breuk met de Rijkspost te kunnen brengen en aan de Rijkspost het passeeren van het gebied van de Paltz, Keulen en Munster te doen verbieden, waardoor deze gedwongen kon worden om alle Italiaansche brieven op Holland en Engeland af te geven, die dan daarna via Emmerik of Kleef konden gezonden worden en verder via Arnhem en Utrecht.

Wanneer Pruisen de brieven tot Aalten bracht, konden de steden die vandaar langs de reeds beschreven route doen halen, waarvoor zij aan Pruisen zeer aannemelijke voorwaarden wilden aanbieden. De correspondentie op Holland zoude hierdoor veel sneller kunnen geschieden, daar thans de brieven uit Polen, Pruisen, Saksen en Hessen soms 2 à 3 dagen te Emmerik bleven liggen, omdat de postiljon naar Holland juist drie uur voor de aankomst van deze brievenmalen vertrok. Door met vier paarden te rijden zoude ook de rijtijd zelf bekort kunnen worden. De Geldersche correspondentie zoude er zeer mede gebaat zijn, indien het rit van Arnhem naar Utrecht in handen kwam van de steden, en deze zouden op deze wijze tevens de bijdrage van 500 gulden per jaar uitwinnen, die zij aan SINGENDONCK moesten betalen.

$\mathrm{Bij}$ de stukken is eene memorie voor den afgevaardigde, die hierover te Keulen met den heer Gansinot, den minister van de Paltz, zoude spreken. LöCKELl, de Pruisische postmeester te Emmerik, scheen het plan niet afkeerig ${ }^{3}$ ) en ook Dierquens toonde in het begin wel eenige medewerking en liet althans voorloopig oogluikend het vervoer van het smokkelpakket met de Wageningsche

1) Brief van VAN RUYven, 22 Januari 1735.

2) Brief van VAs RUYTeN, 26 Januari 1735.

3) Brief van PABST, 4 Februari 1735. 
brieven door CLeynhuysen toe. Zijne medewerking was van het grootste gewicht, daar hij het rit naar Arnhem voor Pruisen beheerde en zijn advies zeker te Berlijn zoude gevraagd worden. $\left.{ }^{1}\right)$ Van beide zijden verminderde later de lust tot medewerking; de postmeester te Emmerik toonde zich weinig geneigd om aan de steden een aandeel te geven in de voordeelen van de brieven, wanneer die feitelijk voor kosten van Pruisen tot Wageningen werden gebracht, en Dierquens trok zich terug, daar hij ernstige oppositie vreesde van den Pruisischen postmeester VAN RAASFELDT te Kleef, van wien hij wist, dat hij met SINGENDONCK bevriend was. VAN RUYYEN raadde daarom aan om in elk geval SingENDONCK aan de praat te houden tot den aanstaanden landdag, ${ }^{2}$ ), ofschoon hij van den anderen kant weder bevreesd was, dat deze onder de hand de plannen te Berlijn zoude tegenwerken.

$\mathrm{Er}$ ontstond zelfs gevaar, dat DIERQUENS het vervoer der Wageningsche brieven door Cleynhuysen zoude stoppen. Wageningen had dien postiljon bewogen om tegen eene kleine vergoeding ook het pakket van Wageningen mede te nemen en had daarna den 19 December 1733 aan Singendonck geschreven, dat het voortaan zelf voor het vervoer van zijne brieven naar Utrecht zoude zorgen. Deze nieuwe verzending begon met I Januari $1734^{3}$ ) en in het eind van 1734 werd de overeenkomst met CLeYNHUYSEN vernieuwd ${ }^{4}$ ), doch dit had slechts waarde, zoolang DIERquens niet tusschen beide kwam. Het medenemen van andere brieven toch was aan den postiljon bij zijne aanstelling uitdrukkelijk verboden op straffe van onmiddellijk ontslag. 5) Het schijnt, dat VAN RUYveN den postiljon heeft gepaaid met de belofte, dat de steden hem in dienst zouden houden, indien het rit door haar werd overgenomen, en wel op dezelfde voorwaarden als bij Dierquens, die hem 800 gulden per jaar betaalde. Met die overeenkomst met CLEYNHUYSEN schijnt Wageningen nog verdere plannen gehad te hebben dan alleen het vervoer der eigen brieven naar Utrecht, althans den 2 Januari 735 schrijft Wigbold Slicher, dat dit eene kwestie was, die alleen Wageningen betrof en waar men de andere steden buiten moest laten. Toch werden de onderhandelingen met Pruisen niet geheel verbroken. Den 8 Februari I735 schrijft W. SchuylenburG, dat hij met Löckell sprak en dat de zaak marcheerde en kort na 10 Februari schrijft VAN RUyven, dat de eerste postzak met vier brieven via CLeynhuysen naar den Pruisischen postiljon buiten Arnhem

1) Brief van Van Ruyven, 26 Januari 1735.

2) Brief van VAN Ruyven, 27 Februari 1735.

3) TоRск bericht 20 December I733, dat de nieuwe dienst is ingericht, en VAN Ruxven meldt 3 I Januari 1734, dat de brieven sinds begin Januari met CLEYNHUYSEN verzonden worden.

4) Brief van Van Ruyven, 29 December 1734.

5) Brief van SLICher, 9 Januari 1735 . 
is gezonden, en dat hij hoopt op die wijze zijne correspondentie op Lunen, Duisburg, Wezel, Kleef en Emmerik te kunnen zenden. Dit was echter een speciaal voordeel voor Wageningen en niet voor de andere steden en VAN RUYVEN verzoekt zelfs aan SCHUYLENBURG om te bewerken, dat de brieven aldus gezonden worden, dat Arnhem er buiten blijft. Ook Doesburg schijnt op eigen hand in I734 een contract gesloten te hebben over het vervoer van brieven via Boekholt en Munster.

Wellicht, dat de vrees, dat Wageningen hem zoude trachten te onderkruipen in het vervoer der Pruisische brieven, DIERQuens tot andere gedachten heeft gebracht. Mogelijk was dit ook de overtuiging, dat de heeren groote plannenmakers waren, doch dat hunne beteekenis voor het brievenvervoer gering was en het onpractisch zoude zijn om voor een zoo gering belang in strijd te komen met de Rijkspost. Wij zien althans, dat DIERquens zich den 9 Januari 1735 tegenover Wigbold Sligher uitliet, dat VAN RUyven zelf maar eens bij hem moest komen om te toonen wat voor correspondentie hij eigenlijk had, en dat ongeveer van dat oogenblik af DIERQUENS een gereserveerde, zoo niet een vijandige houding begon aan te nemen.

Onder deze omstandigheden is het niet te verwonderen, dat de andere steden naar een einde van den strijd verlangden, te meer daar ook SINGENDONCK, die schade leed door het lang uitblijven van de afrekening met de steden, haar eenigszins tegemoet gekomen schijnt te wezen. $\left.{ }^{1}\right)$ Hij verzocht eene conferentie met de steden, welke daarop den 28 Juli 1735 plaats vond. Wat daar verhandeld is, blijkt niet, daar de correspondentie hier eindigt. De notulen van Arnhem en Zutphen geven echter voldoende het verloop aan. Volgens de raadsresolutie van Zutphen van 30 Juli I 735 gaf VERSTEGE een uitvoerig verslag van het gebesoigneerde, doch werd dit in deliberatie aangehouden tot de "Heeren Ed. en Achtb. in completer getal vergadert sullen zijn." Den 30 September werd nader door VERSTEGE en HASEBROECK rapport gedaan ,wegens 't gebesoigneerde tot Arnhem, soo onder de respective steden, als met de Heer SINGENDONCK, aengaende de saak der posterije, en van 't geconvenieerde met den laestgemelten." De Heeren werden voor hunne moeite bedankt en E. J. B. van Goltstein, G. J. SChIMMELPENNinck VAN DER OYF en G. VERSTEGE werden gecommitteerd om het "accoord off convenien tie met de Heer SiNGENDONCK te perfacteeren ende te ondertekenen". Te Arnhem rapporteerden de gecommitteerden den 12 October 1735, dat ,nae menigvuldige gehouden conferentien - eyndelijk de saken soo verre gebragt hadden, dat niet alleen met de Heeren van Nijmegen over de kosten en transporten der brieven als

1) Brief van Torck, Io Mei 1735.

Oud-Holland, 1916. 
anders op den 8en deses hadden geconvenieert, maer ook op den to daeraen volgende met de Heeren Gecommitteerden der steden Zutphen en Doesburgh, wat ieder stad in die kosten soude dragen en aen het Nijmeegsch contoir jaerlijx fourneeren, hadden gereguleert". 1) De conventie werd daarop geratificeerd. Het resultaat was, dat den 8 October $\mathbf{1 7 3 5}$ door Arnhem, Zutphen en Doesburgeen contract met SINGENDONCK werd gesloten, waardoor deze drie steden haar verzet opgaven. ${ }^{2}$ ) Alleen Wageningen volhardde nog, doch dit had alleen een te weinig belangrijk brievenvervoer om op den duur den strijd te kunnen volhouden. Ook deze stad legde eindelijk het hoofd in de schoot en sloot den I7 Mei I737 eene overeenkomst met SingENDONCK.

Deze had dus over de geheele linie gezegevierd en de gevolgen hiervan bleven niet uit. De steden, die eerst gehoopt hadden buiten Nijmegen om een eigen weg voor hare correspondentie te vinden, sloten later zelfs een contract met den postmeester te Nijmegen, waarbij deze ook het rit van Wageningen naar Dieren tegen eenige vergoeding op zich nam, zoodat zij alle aanraking met de vreemde postmeesters verloren. Het zoogenaamde Schuylenburgsche rit van de Pruisische post, hetwelk de vier steden zoo gaarne onder haar beheer hadden gekregen, ging later in 1762 over aan de Statenpost in Holland, waardoor deze provincie ook in Gelderland een overwegenden invloed verkreeg op het postwezen. De ontwikkeling van het postwezen ware allicht anders, en voor de Geldersche steden gunstiger geweest, indien de grootsche plannen der vier steden in I 735 meer succes hadden gehad.

1) Commissie en Politieboek van Arnhem deel ${ }^{729-1755}$ blz. 506. Deze aanteekeningen dank ik aan welwillende mededeelingen van de Heeren J. Gimberg te Zutphen en J. W. G. van Haarst te Arnhem.

2) Zie mijne Geschiedenis van het Postwezen blz. 479. De bijdrage aan Singendonk voor het rit van Wageningen naar Utrecht werd hierbij teruggebracht tot 250 gulden. De correspondentie van Arnhem bedroeg in 1734: 11267 Hollandsche en 6008 bovenlandsche brieven. 
$B I F L A G E$.

\section{BRIEF VAN VAN RUYVEN AAN TORCK, 5 Januari 1735.}

„Nu wij aan het kluwen geraaken vinde ik niet die avantage voor onse stad, die ik mï altoos verbeeld hadde, namentlijk om afsonderlijk onder d'hand meester van de Berlijnsche postrit te werden, en in cas van rupture daermede een klegne avantage te trecken voor onse postmeester.

Maar d'ouverture van confrater SLICHER en UEb. Welgeb. Gestrs, consideratien determineren mij nu salve meliore om van dat kleyne voordeel af te sien en sulx te moeten doen, want d' uytkeeringe van 750 glns is een ieder bekent, en blijkt nu voor $25^{\circ}$ glns gehegt aan de Berlijnsche postrit, concludeerde ik soude nu van gevoelen sijn, edogh alles onder UH. Welgeb. Gestrs approbatie, dat wij d' handelinge over de Berlijnsche postrit met geen gratie ter wereld nogh met hoope van succes sullen kunnen ten eynde brengen voor onse stad in 't particulier, maar dat wij die op de naam en ten voordeele der vier steeden behooren te sien meester te werden, en dat men vooraf communicative met de drie steeden nader met d'Heer DiERQueNs behoorde te spreeken en de concert overleggen, hoedanigh sulx bequaamst door d'Hr. VAN GINKEL aan de Coningh van Pruysschen; smakelijk te maken, want d'Hr. van Dieden - (d.i. SiNGENDONCK) - weten wij dat d'Hr. RAASveldT postmeester van 't land van Cleve reets gepraeoccupeert heeft, en dat de Postmrs van (Emm)erik daardoor geintimeert is.

Als de vier steeden d'Hr. DIERQuens tot een favorabel advis kunnen brengen, hebbe ik een speculatie of men door d'authoriteyt van Sijn Pruysische Majt. niet soude kunnen obligeren de Keyserlijke Comptoiren om de bovenlandsehe brieven voor de 4 steeden over Emmerik terugh te senden, en soude ook sijn speculatie hebben of de Cleefsche Postmrs niet souden t'induceren sijn om tusschen Emmerik en Cleve een postillon aan te leggen, dan souden alle de brieven voor het land van Cleve over Arnhem en Emmerik, en geene over Nijmegen behoeven te loopen, gevolghlijk het comptoir van Nijmegen niet behoeven te participeren in de $75^{\circ}$ glns. Ook souden mogelijk de vier steeden haare brieven over Cleve na Braband kunnen senden en ook ontfangen, houdende voor die naar Vlaanderen de route over Utrecht. (enz.),

(get. ) D. VAN RUYVEN.

1) De 250 gulden werden betaald voor het vrij verkeer van den postiljon en 500 gulden voor het vervoer der brieven over Nijmegen. Wigbold SLiCher bewerkte bij Dierquens, dat deze $75^{\circ}$ gulden voorloopig niet betaald werden. (Brief van 9 Januari 1735 ).

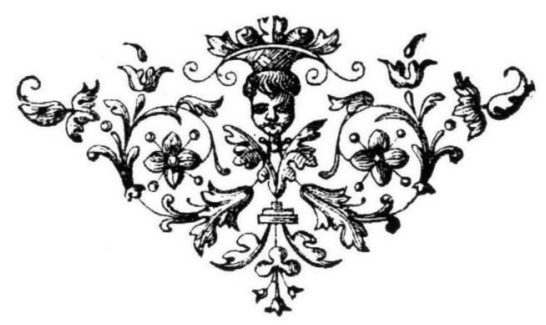

